\title{
An Educator's Credo: They Don't Learn What You Expect, But What You Inspect
}

\author{
Joseph F. O’Donnell
}

Published online: 1 February 2011

(C) Springer 2011

It may be sad, but true. Evaluation drives learning mercilessly, and as cancer educators, we must pay careful attention to what we inspect to help our students to learn what we expect.

This is an era of competencies. I have written before of the Accreditation Council on Graduate Medical Education's list of six core competencies-medical knowledge, skills, communication, professionalism, practice-based improvement, and system-based practice. Those "assessing" undergraduate and continuing medical education, as well as education for the other health professions, are talking the competency lingo too, so we must jump aboard.

In this editorial, I wanted to make JCE readers aware of two important (I think) offerings in this domain and one framing diagram for assessment in general.

The first of the offerings is a Consensus Document and Recommendations for Assessment that came from the Ottawa 2010 Conference on Assessment (available at www.ottowaconference.org). The Ottawa Conferences on the Assessment of Competence in Medicine and the Healthcare Professions were set up by Professor Ian Hart (Ottawa, Canada) and Professor Ronald Harden (Dundee, UK) in 1985. Held biennially, they have provided a forum for educators in medical and other healthcare professions to network and share ideas on all aspects of the assessment of competence in both clinical and non-clinical domains throughout the continuum of education. In 2010, the conference-held in Miami, Florida in May-celebrated its 25th anniversary; its participants reviewed the progress made over the past 25 years, highlighted current best

J. F. O’Donnell ( $\square)$

Dartmouth Medical School,

Hanover, NH, USA

e-mail: Joseph.F.ODonnell@Dartmouth.EDU practices, and identified trends and developments for the next 25 years.

On the website above are reports from six theme groups (Criteria for Good Assessment, Technology Enabled Assessment of Health Professional Education, Performacebased Assessments, Assessment of Professionalism, Assessment for selection for Healthcare and Specialty training, and Research on Assessment). Each group was comprised of international experts, and their product (ten pages filled with gold nuggets!) is priceless for educators. Go get it - it will help you in your work and help all of us provide better cancer education and cancer care. There were many pearls for me- - one was the catalytic (isn't that a great word, and a great image for an educator?) role that assessment can play in driving, enhancing, and supporting education.

The second important offering is the book by Molly Cooke, David Irby, and Bridget O'Brien called Educating Physicians: A Call for Reform of Medical School and Residency [1]. This was one product in a whole series of indepth looks at the preparation of nurses, lawyers, engineers, clergy, and doctors, supported by the Carnegie Foundation for the Advancement of Teaching. The medical education report has been dubbed "the new Flexner Report," and it is hoped that this new one from Carnegie will have as much influence in reforming medical education as its predecessor did in the early part of the last century. It is built around four I's-Individualization, Integration, Insistence on excellence, and attention to the formation of professional Identity. Insistence on excellence entails setting up robust evaluation systems. The authors' thesis is that the pathways students take to their goals should be individualistic, but that assessment must be rigorous to ensure that the goal is met, and if we pay attention to what we INspect, the students will do what we expect. This book, and indeed, all the books in the Carnegie Series, are worth our attention. 
Table 1 Parker Small's evaluation table

\begin{tabular}{lll}
\hline & Formative & Summative \\
\hline Self & +++ & ++ \\
Peer & +++ & ++ \\
Faculty & + & ++ \\
National & 0 & ++ \\
\hline
\end{tabular}

There are many lessons that each profession can teach others, and perhaps by learning these, we can raise the bar and improve the processes for everyone.

My third message about evaluation comes from the work of Parker Small, a noted medical educator from the University of Florida. I have always found his table (Table 1) to be very useful. Formative evaluation should be heavy on self and peer domains, but Parker often opines that medical education is too "selfless and peerless," and that formative evaluations might be better if we could encourage more (and more effective) self and peer evaluations. Summative evaluations should be balanced with equal doses of self, peer, faculty, and national domains (e.g., national board-type exams), but this distribution is surely not the case.

In summary, educators must learn to use all of the tools for inspection - so read that Ottawa Conference material, digest the Carnegie tome of wisdom, and think about Parker Small's table - can we get more self and peer evaluation in the mix? Insist on excellence and measure it well.

Enjoy this issue, and while you're reading about the good work these authors are doing, think about coming to the next EACE meeting on International Collaboration in Cancer Education and Palliative Care: Improving Practice through Education in Nicosia, Cyprus March 9-11, and mark your calendars and send in abstracts for the 2011 AACE/EACE/CPEN meeting in Buffalo from September 8 to September 10, 2011.

\section{Reference}

1. Cooke M, Irby D, O'Brien B (2010) Educating physicians: a call for reform of medical school and residency. Jossey-Bass 